\title{
2 TIPO CUKRINIS DIABETAS: EPIDEMIOLOGIJA, RIZIKOS VEIKSNIAI IR DIAGNOSTIKOS KRITERIJAI
}

\author{
Aistė Naujokaitytè \\ Vilniaus universiteto Medicinos fakultetas
}

Raktažodžiai: 2 tipo cukrinis diabetas, cukrinio diabeto epidemiologija, rizikos veiksniai, diagnostikos kriterijai.

\begin{abstract}
Santrauka
2 tipo cukriniam diabetui būdinga hiperglikemija, atsparumas insulinui ir santykinis insulino sekrecijos sutrikimas. Didejjanti 2 tipo diabeto našta kelia didelị susirūpinimą pasaulio sveikatos priežiūros sistemoms. Cukrinis diabetas yra devintoji pagrindinè mirtingumo priežastis pasaulyje. Šios ligos patogeneze suprantama tik iš dalies, tačiau ji yra nevienalytė, nes svarbūs tiek genetiniai veiksniai, turintys įtakos insulino išskyrimui ir jautrumui, tiek aplinkos veiksniai, pavyzdžiui, nutukimas. Tyrimo tikslas - ịvertinti, susisteminti ir išanalizuoti mokslinejje literatūroje pateikiamus duomenis apie 2 tipo cukrinị diabetą, epidemiologiją, reikšmingus rizikos veiksnius, galinčius turèti ịtakos šios ligos vystymuisi bei diagnostinius kriterijus.
\end{abstract}

\section{Ivadas}

2 tipo cukriniam diabetui būdinga hiperglikemija, atsparumas insulinui ir santykinis insulino sekrecijos sutrikimas. Didejjanti 2 tipo diabeto našta kelia didelį susirūpinimą pasaulio sveikatos priežiūros sistemoms. Cukrinis diabetas yra devintoji pagrindinè mirtingumo priežastis pasaulyje. 2017 m. 2 tipo cukriniu diabetu sirgo maždaug 462 milijonai asmenų, t.y. 6, 28 proc. pasaulio gyventojų [1]. Šios ligos patogenezè suprantama tik iš dalies, nes ji nevienalytė ir svarbūs tiek genetiniai veiksniai, turintys ịtakos insulino išskyrimui ir jautrumui, tiek aplinkos veiksniai, pavyzdžiui, nutukimas. Svarbu suprasti, kad sveikas ir aktyvus gyvenimo būdas [2], tam tikra dieta, pavyzdžiui, kurioje gausu vaisių, daržovių, riešutų, viso grūdo produktų bei alyvuogių aliejaus, yra veiksniai, mažinantys 2 tipo cukrinio diabeto riziką [3].

Tyrimo tikslas - išanalizuoti ir aptarti įrodymais pagrịstą informaciją apie 2 tipo cukrinio diabeto epidemiologiją, rizikos veiksnius bei diagnostiką.

\section{Tyrimo medžiaga ir metodai}

Taikyta sisteminė mokslinès literatūros bei dokumentų apžvalga ir analizè. Duomenų buvo ieškoma Google Scholar, UpToDate, Cochrane bei Medline (PubMed) duomenų bazèse. Visateksčiai straipsniai atrinkti, jei jų pavadinimas, santrauka ar reikšminiai žodžiai nurodè, kad tyrimas tinkamas įtraukti ị šią apžvalgą. Pasirinktos tik anglų kalba skelbtos publikacijos. Vartoti nurodyti raktažodžiai. Atrinkti, išanalizuoti ir apibendrinti 5 straipsniai.

\section{Tyrimo rezultatai}

Epidemiologija. 2017 m. 2 tipo cukriniu diabetu sirgo maždaug 462 milijonai asmenų, t.y. 6,28 proc. arba 6059 atvejų 100000 pasaulio gyventojų (15-49 m. 4,4 proc., 50-69 m. 15 proc. , 70 ir daugiau m. -22 proc.). Diabetui galima priskirti daugiau kaip 1 milijoną mirčių per metus. Tai devintoji pagrindine mirtingumo priežastis pasaulyje. Cukrinio diabeto atvejų sparčiai daugejja išsivysčiusiuose regionuose, pavyzdžiui, Vakarų Europoje. Sergamumo pasiskirstymas tarp lyčių yra vienodas, o liga dažniausiai nustatoma 55 metų asmenims. Prognozuojama, kad 2 tipo cukrinio diabeto paplitimas pasaulyje iki 2030 metų padidès iki 7079 atvejų 100000 gyventoju [1]. Sergančiujų diabetu skaičius labiausiai dideja išsivysčiusiose ir besivystančiose pasaulio šalyse ir sudaro apie 3-8 proc. per metus [4].

Rizikos veiksniai. Iš atrinktų 86 reikalavimus atitikusių straipsnių, buvo nustatyti 2 tipo cukrinio diabeto rizikos veiksniai, apimantys įvairius biožymenis, sveikatos būkles, mitybos, gyvenimo būdo, aplinkos ir psichosocialinius veiksnius. Pateikti tvirti įrodymai, kad 2 tipo cukrinio diabeto rizikos veiksniai yra didelis riebalų kiekis kūne, maža klubų apimtis, serumo biožymenys (padidejęs alanino aminotransferazès, gama- glutamiltransferazès, šlapimo rūgšties ir C reaktyvaus baltymo koncentracija, sumažejęs adiponektino ir vitamino D kiekis), nesveika mityba (padidejęs perdirbtos mésos ir cukraus vartojimas: saldinti gèrimai, kava, sumažejjęs neskaldytų grūdų ir hemo geležies vartojimas bei kitų 
sveikos mitybos rekomendacijų nesilaikymas), žemas išsilavinimo ir sąmoningumo lygis, sumažèjęs fizinis aktyvumas, ilgas sėdejjimo laikas per dieną, ilga televizijos žiūrẻjimo trukmè, alkoholio vartojimas, rūkymas, oro tarša ir kai kurios sveikatos būklès (aukštas sistolinis kraujospūdis, vèlyva menarchès pradžia, nëščiųjų diabetas, metabolinis sindromas, neišnešiotumas) [2]. Teigiama šeimos anamnezè, miego stygius, gimimo svoris bei nutukimas vaikysteje yra galimi 2 tipo cukrinio diabeto rizikos veiksniai. Netinkama mityba gali būti ne tik šios ligos išsivystymo veiksnys, tačiau tam tikra dieta, kurioje yra, pavyzdžiui, daug vaisių, daržovių, riešutų viso, grūdo produktų bei alyvuogių aliejaus, mažina 2 tipo cukrinio diabeto riziką [3].

Diagnostikos kriterijai. Remiantis Amerikos diabeto asociacijos gairèmis, 2 tipo cukrinis diabetas diagnozuojamas, kai alkio glikemija $\geq 7 \mathrm{mmol} / 1$ arba glikemija 2 valandos po $75 \mathrm{~g}$ gliukiozès testo $\geq 11,1 \mathrm{mmol} / \mathrm{l}$, arba atsitiktinai pamatavus gliukozės koncentraciją kraujyje pacientams, su klasikiniais hiperglikemijos simptomais, arba ištikus hiperglikeminei krizei, ji yra $\geq 11,1 \mathrm{mmol} / 1$ arba $\mathrm{HbA} 1 \mathrm{c}$ reikšmé $\geq 6,5$ procento [5].

\section{Išvados}

1. Sergamumas ir 2 tipo cukrinio diabeto paplitimas pasaulyje sparčiai didejja ir tai yra viena iš dažnesnių žmonių kančių ir mirties priežasčių.

2. Nors atsparumas insulinui ir sutrikusi insulino sekrecija sergant 2 tipo cukriniu diabetu turi esminị genetini komponentą, poveiki gali daryti ir elgesio veiksniai, tokie kaip fizinis aktyvumas, dieta, rūkymas, alkoholio vartojimas, kūno svoris ir miego trukmè.

3. Cukrinio diabeto diagnozè lengvai nustatoma, kai pacientui pasireiškia klasikiniai hiperglikemijos simptomai ir jo atsitiktiné plazmos gliukozės vertė yra $11,1 \mathrm{mmol} / 1$ arba didesnè. Asimptominiams asmenims diagnozè nustatoma remiantis Amerikos diabeto asociacijos kriterijais.

\section{Literatūra}

1. Khan MAB, Hashim MJ, King JK, Govender RD, Mustafa H, Al Kaabi J. Epidemiology of type 2 diabetes - global burden of disease and forecasted trends. J Epidemiol Glob Health 2020;10(1):107-11.

https://doi.org/10.2991/jegh.k.191028.001
2. Bellou V, Belbasis L, Tzoulaki I, Evangelou E. Risk factors for type 2 diabetes mellitus: an exposure-wide umbrella review of meta-analyses. PLoS One 2018;13(3).

https://doi.org/10.1371/journal.pone.0194127

3. Robertson RP. Risk factors for type 2 diabetes mellitus. UpToDate 2021.

4. Diabeto epidemiologija. https://www.cukrinisdiabetas.lt/lt/ diabeto-epidemiologija

5. Anastasopoulou C. Type 2 diabetes diagnostic criteria by the ADA: type 2 diabetes ADA diagnosis criteria. 2020.

\section{TYPE 2 DIABETES MELLITUS: EPIDEMIOLOGY, RISK FACTORS AND DIAGNOSTIC CRITERIA}

\section{A. Naujokaitytė}

Keywords: Type 2 diabetes, epidemiology of diabetes, risk factorsdiagnostic criteria

Summary. Type 2 diabetes is characterized by hyperglycemia, insulin resistance, and relative impairment of insulin secretion. The growing burden of type 2 diabetes is a major health concern and the ninth leading cause of mortality in the world. The pathogenesis of this disease is only partially understood, but it is heterogeneous and important for both genetic factors affecting insulin secretion and sensitivity and environmental factors such as obesity. The aim of this study was to evaluate, systematize and analyze the data presented in the scientific literature on type 2 diabetes, epidemiology, significant risk factors that may affect the development of this disease and diagnostic criteria.

Conclusions.

The incidence and prevalence of type 2 diabetes in the world continues to rise rapidly and is one of the leading causes of human suffering and death.

Although insulin resistance and impaired insulin secretion in type 2 diabetes have a substantial genetic component, they can also be influenced, both positively and negatively, by behavioral factors, such as physical activity, diet, smoking, alcohol consumption, body weight, and sleep duration

The diagnosis of diabetes mellitus is easily established when a patient presents with classic symptoms of hyperglycemia and has a random plasma glucose value of $11.1 \mathrm{mmol} / 1$ or higher. The diagnosis of diabetes in an asymptomatic individual can be established based on the American Diabetes Association criteria.

Correspondence to: aiste.naujokaityte@mf.stud.vu.lt

Gauta 2021-04-22 